\title{
Behaviour of Some Round Pepper Lines Tested in the Comparative Plots for Evaluation
}

\author{
Gicuţa SBIRCIOG ${ }^{1)}$ \\ 1) Research and Development Institute for Vegetable and Flower Growing Vidra, Romania. \\ ${ }^{*}$ Corresponding author, e-mail: ralldom@yahoo.com
}

Bulletin UASVM Horticulture 72(1) / 2015

Print ISSN 1843-5254, Electronic ISSN 1843-5394

Doi:10.15835/buasvmcn-hort:10824

\begin{abstract}
During the 2012-2013 period in the frame of the experimental field of RDIVFG VIDRA, 5 round pepper lines, created at the Plant Breeding Department of the Institute between the years 2005-2013, were investigated under comparative plots for evaluation. The yield capacity and fruits' quality have been watched, using as a control variety the cultivar Cornel 209. Several observations and morphological determinations were carried out aiming the following characteristics: total yield, number of fruits per plant, fruits' shape and color. The results emphasized that the best behaviour had the lines LVG54/2009 by comparison with the control variety.
\end{abstract}

Keywords: genotypes, lines, round pepper, variety.

\section{INTRODUCTION}

Among the vegetable species cultivated in our country, the pepper (Capsicum annuum L.) plays an important role, having many uses. The pepper fruits can be consumed fresh while presenting a great importance for their high nutrition value and the fact that the vitamins are wholly used by the human body (Sbîrciog, 2012). The fruits' chemical composition is very complex. The content of $\mathrm{C}$ vitamin depends on the fruits' maturity degree, colour and size (Ciofu et al., 2003; Sbîrciog, 2003; Somos, 1984). The culture conditions influence the content of $\mathrm{C}$ vitamin, this being higher for the field crops, as compared to the greenhouse crops. There is a big diversity worldwide as regarding the types and hybrids of peppers, with different shapes and colours of the fruits, depending on the consumer's taste (Pintilie and Glăvan, 2004).

\section{AIMS AND OBJECTIVES}

The research was done during the years 20052013 at RDIVFG Vidra as part of the research topic and aimed at obtaining some new pepper cultivars (types and hybrids), with higher productions as compared to the current genotypes from the national variety, which should be resistant to biotic and abiotic factors. The studies aimed at assessing the biological material obtained, in order to select the most valuable genotypes to be tested within the SIVTR network.

\section{MATERIALS AND METHODS}

The biological material was formed of five round pepper lines, obtained from the intraspecific pollination among valuable pepper varieties and lines, followed by the pedigree selection and bulk positive selection yearly repeated, until F7 generation. The five lines have been studied in the comparative plots for their behavior during the years 2012-2013, following the randomized blocks method in four replication, using the cultivar Cornel 209 as control. During the vegetation period, various observations and biometrical determinations, according to the UPOV sheet, have been performed. The harvest and record of the yield were made in dynamics, by determining the total average yield ( $\mathrm{t} / \mathrm{ha}$ ) and relative yield (\%), in order to establish the production potential of the new round pepper genotypes,.The production data were statistically processed by using the analysis of variance, while the level of significance of the production differences was established by means of the limit difference (Ciulca, 2002).

\section{RESULTS AND DISCUSSION}

The analysis of the production obtained for the five lines under study shows that the production 
Tab. 1. Production analysis for round pepper genotypes.

\begin{tabular}{ccccc}
\hline Cultivar & Average yield (t/ha) & Relative yield (\%) & $\begin{array}{c}\text { Difference } \pm \text { as compared } \\
\text { to control variety }\end{array}$ & Significance \\
\hline LVG54/2009 & 53.2 & 107.04 & +3.5 & $*$ \\
LVG 41/2001 & 51.5 & 103.62 & +1.8 & $*$ \\
Cornel 209 (control) & 49.7 & 100.00 & - & - \\
LVG31/2009 & 46.7 & 93.96 & -5.8 & 0 \\
LG19/2008 & 43.9 & 88.32 & -5.9 & 00 \\
LVG31/2009 & 43.8 & 88.12 & LSD $0.1 \%=6.8 \mathrm{t} / \mathrm{ha}$ & 00 \\
LSD 5\%=1.7 t/ha & LSD 1\%=4.2 t/ha & & \\
\hline
\end{tabular}

varied between $53.2 \mathrm{t} / \mathrm{ha}$ for the LVG54/2009 line and $43.8 \mathrm{t} / \mathrm{ha}$ for the LVG31/2009 line. Higher average yields as compared to the control variety Cornel 209 (49.7t/ha) have only been achieved by two lines: LVG54/2009 (53.2 t/ha) and LVG41/2010 (51.5 t/ha). The other three lines under study achieved lower average yields as compared to the control variety, between 46.7 t/ha (LVG31/209) and 43.8 t/ha (LVG31/2009). The yield differences for all 5 genotypes under observation as compared to the control are statistically significant, out of which positively significant for two genotypes and negatively significant for 3 genotypes. Negative significant yield differences as compared to the control were found with the genotypes LVG31/209 (-3.0 t/ha), LG19/2008 (-5.8t/ha) and LVG31/2009 (-5.9 t/ ha) respectively (table 1 ).

At this species with continuous growth, once the flowering and fruit formation process is started, it is continued until the early autumn hoarfrost, considering that optimal plant development conditions are ensured. It is preferable that the period from emergence to the first flowers' appearance to be as short as possible, the same as the period from flowering to the fruits' formation. For a better evaluation of the different physiological periods of the genotypes under analysis, the sum of active temperature degrees, necessary for the crops' formation, was determined. Among the genotypes under analysis there are significant differences in this respect, the LVG 54/2009 line being clearly distinguished $\left(1950^{\circ} \mathrm{C}\right.$ from emergence to physiological maturation). The results shown in the table 1 represent the average values of the two years of experiments. Among the genotypes under study, the LGV54/2009 line for the field culture was particularly distinguished, being intended for consumption in fresh condition and for industrialization. The plant is vigorous (50-60 cm height) with round flattened fruits, with an average weight of $150 \mathrm{~g}$, being darkgreen coloured before ripening and shiny intense red at the physiological maturity. The obtained results in this study confirm previous results on the behavior of the pepper lines in comparative plots for yield evaluation (Sbîrciog, 2012; Pintilie 2004).

\section{CONCLUSION}

The study of the five round pepper lines revealed that only two lines achieved higher yields as compared to the control, with statistically significant yield differences, while the LVG 54/2009 line particularly distinguished itself, with an average yield of $53.2 \mathrm{t} / \mathrm{h}$. The LVG 54/2009 line was submitted for testing within the SIVTR network.

\section{REFERENCES}

1. Ciofu R, Stan N, Popescu V, Pelaghia C, Apahidean S, Horgoș A, Berar V. Lauer KF, Atanasiu N (2003). Tratat de legumicultură. Editura Ceres. București.

2. Ciulca S (2002). Tehnică experimentală. Editura Mirton. Timișoara.

3. Pintilie I, Glăvan L (2004). Studiul resurselor de germoplasmă autohtone și străine la ardeiul gras (Capsicum annuum L. ssp. annuum, conv. grossum L.), în vederea utilizării acestora în procesul de ameliorare. Anale I.C.D.L.F. Vidra 2004, XVII: 183-196.

4. Sbîrciog G (2003). Intensitatea fenomenului heterozis la ardei. ASAS București PhD Thesis.

5. Sbîrciog G (2012). New Pepper (Capsicum annuum L.) Genotypes Created at ICDLF Vidra. Bulletin UASVM ClujNapoca.Horticulture 69(1):425.

6. Somos A (1984). The Paprika. Akademiai Kiado, Budapest. 